\title{
Kreis und Kugel
}

von

\section{Dr. Wilhelm Blaschke}

a. o. Professor an der Universität Leipzig

Mit 27 Figuren im Text

Leipzig :: Verlag von Veit \& Comp. :: I9I6 
Druck von Metzger \& Wittig in Iolpzig. 
Oskar Freiherrn von Lichtenfels gewidmet 
